\title{
Improved Baby Lactation Management and Stimulation for Family Welfare Empowerment (FWE)
}

\author{
Siti Hamidah, Zufra Inayah \\ Midwifery, Faculty of Health, \\ Muhammadiyah University of \\ Gresik \\ Email: \\ sthamidahtw@gmail.com
}

Received : October $4^{\text {nd }} 2021$

Accepted : October $15^{\text {rd }} 2021$

Published : November $27^{\text {th }} 2021$

\begin{abstract}
Background : Exclusive breastfeeding is breastfeeding alone without additional food, including water during breastfeeding, except for medical indications. Breast milk and baby stimulation support optimal health, growth and development of babies. Exclusive breastfeeding is recommended as long as it is still sufficient for the baby's needs, breastfeeding has an effect on brain development, and is effective in improving children's cognitive understanding, but exclusive breastfeeding has not reached the expected target. The aim of this research is; (1) Provide learning about lactation management and infant stimulation, (2) To determine the effect of the workshop on the knowledge and skills of Family Welfare Empowerment (FWE) mothers regarding lactation management and infant stimulation.

Materials And Methods : Quasi-experimental design research, conducted in Gresik Regency, East Java. Research time; February to June 2021. A sample of 80 people was selected by quota sampling. The dependent variable is skills in breastfeeding practice and baby stimulation. The independent variable was a workshop on lactation management and infant stimulation. Data collection using questionnaires and observation sheets. Data were analyzed using t test.

Results : The mean value of breastfeeding practice correctly after the workshop (mean=86.80 $\mathrm{SD}=4.16$ ) was higher than before the workshop (mean=; 48.52; SD=8.69), and statistically significant $(\mathrm{p}<0.001)$, and the score was statistically significant $(\mathrm{p}<0.001)$. the average stimulation skills of infants 3-6 months after the workshop (mean $=87.89 ; \mathrm{SD}=3.53$ ) were higher than before the workshop (mean=53.88; $\mathrm{SD}=8.76$ ), and statistically significant $(\mathrm{p}<0.001)$.

Conclusion : Knowledge about lactation management and infant stimulation is still not widely known to the public. Support from families and the surrounding community, especially mothers for Family Welfare Empowerment (FWE), is needed to disseminate knowledge and lactation management.
\end{abstract}

Keywords: Workshop, lactation management, stimulation 


\section{ShareAlike 4.0 International License.}

\section{INTRODUCTION}

The success of children in achieving optimal growth and development will affect the child's future. The first 1000 days of life (starting in the womb until the age of two years), is a golden period that is very important in the growth and development of children. Exclusive breastfeeding is continued for up to two years, balanced nutrition for infants and children, proper parenting, and proper stimulation are important.

Exclusive breastfeeding is breastfeeding alone without the addition of other foods, including water during breastfeeding (except vitamins, medicines, mineral drops and expressed breast milk) for indications medical (Ministry of Health, 2013). Breast milk affects the development of early white matter and brain myelin, and is effective in improving children's cognitive understanding (Deoni et al, 2013; Benard, 2013; Silvers et al, 2012; Kramer, 2008; Quigley, 2012; and Huang et al, 2014). Breast milk contains complete nutrition for 6 months of age, and no substitute for breast milk is recommended. Furthermore, breastfeeding is continued until the age of 2 years with complementary foods. Breastfeeding has so many health benefits for mothers and babies both during breastfeeding and in the future (Alimoradi, 2014).

The growth and development of a child's brain in this early stage affects the growth and development of children in later stages, which in turn will determine the quality of life both in the short and long term (Santrock, 2007; Ministry of Health, 2016).

WHO recommendations (2018) stated: (1) Early initiation of breastfeeding immediately after birth, (2) Exclusive breastfeeding for the first 6 months of life, unless there is a medical recommendation, (3) Provision of adequate and safe (solid) food with nutrition after age 6 months and continue breastfeeding until two years of age. In this relationship, the mother should be given counseling and support. UU no. 36/2009 Article 128 on health states; "Exclusive breastfeeding is the right of a baby from birth for 6 months, unless there is a medical indication". Families, communities and governments from the center to the regions must provide support to mothers to breastfeed. PP No. 33/2012 mentions; Exclusive breastfeeding is the responsibility of the provincial government. Furthermore, East Java Governor Regulation Number 11 of 2011, and Regency Regional Regulations, namely Gresik Regent Regulation Number 1 of 2015.

Exclusive breastfeeding coverage in Indonesia and in other countries has not yet reached the $80 \%$ target (WHO target, 2018), while up to 2030 it is $70 \%$. According to WHO and UNICEF in 2019, data on exclusive breastfeeding from 2013 to 2018 in the world was $41 \%$. According to the Ministry of Health, the coverage of exclusive breastfeeding in Indonesia; in 2013 (54.35\%); in 2014 (52.3\%); 2015 (55.7\%); 2016 (29.5\%); in 2017 (35.73\%), and according to the results of Riskesdas (2013 - 2018) shows an average exclusive breastfeeding coverage of $37.3 \%$.

Data from East Java Province shows the coverage of exclusive breastfeeding in 2013 (68.48\%); in 2014 (72.89\%); in 2015 (74.1\%), in 2016, (48.1\%); and 2017 (34.92\%) (Ministry of Health, 2018). In Gresik Regency, coverage of exclusive breastfeeding in 2013, (66.16\%); in 2014 (68.9\%); 2015 (70.9\%); 2016 (55.72); and in 2017 (60.60\% (Dinkes Gresik 2018).

Not giving exclusive breastfeeding can trigger malnutrition in toddlers. In 2013 according to National Development Planning Agency and UNICEFF, 12\% of the world's children under the age of five were wasting (low weight compared to height), and approximately the same number were 
overweight. According to data from the Indonesian Ministry of Health (2018), various kinds of nutritional problems for toddlers are still a serious problem in Indonesia. These nutritional problems can trigger the IMR (Infant Mortality Rate). In addition, the impact of not being breastfed; (1) Infants get sick easily (respiratory tract infections, gastrointestinal tract infections and diarrhea (Spaulding et al, 2009; Silvers et al, 2012), (2) Obesity (Ibrahimzadekar et al, 2012; Cartagena et al, 2014), (3) Diabetes and Hypertension (Gunderson et al, 2008; Mayer et al, 2008; Villegas et al, 2008; Stuebe et al, 2009; Schwarz et al, 2010;).(4) Asthma and Allergy (Schnooyi et al, 2012; Silvers et al, 2012).

Breastfeeding is effective in the growth and cognitive development of children (Kramer et al, 2008; Quigley et al, 2012; Bernard et al, 2013). Malnutrition that occurs in the first 1000 days of life will have a severe and irreversible impact (Syarif et al, 2015). The first 1000 days of life is a golden period, so nutrition is important. In addition, stimulation must also be carried out to achieve the growth and development of the child's brain. According to Santrock (2007) and the Ministry of Health (2016), the growth and development stages of Early childhood affects the growth and development of children at later stages, which in turn will determine the quality of life both in the short and long term.

Many studies have been conducted on breastfeeding support to increase the duration of exclusive breastfeeding, but the coverage of exclusive breastfeeding has not been able to achieve the expected target. For this reason, other support intervention research is needed. Prior to this research, in 2019 to 2020 we conducted a study involving the religious women's organization Aisyiyah in Gresik Regency, on the grounds that there were only 1 (one) person breastfeeding counselor for the Aisyiyah organization. To disseminate the importance of the success of exclusive breastfeeding and infant stimulation, the researchers will involve the mothers of Family Welfare Empowerment (FWE) in Gresik district. The aim of this research is; (1) Providing workshops on lactation management and infant stimulation, (2) To determine the effect of the workshop on the knowledge and skills of FWE mothers regarding lactation management and infant stimulation.

\section{MATERIALS AND METHODS}

Research Design : The method used is a quasi-experimental with a before and after design. The location of the workshop is in Karangpoh kelurahan, Gresik Regency, East Java, held from February to June 2021. The workshop is held for 1 day, taking place at Neighborhood Association (NA)1, Citizens Association (CA) 05, NA 2, CA 05, NA 3, CA 05, NA, CA 04.

Population and Sampling Technique : The population in this study were FWE women totaling 368 people. A sample of 80 people was selected by quota sampling.

Research Variables : The dependent variable is the skills of FWE mothers in providing breastfeeding practices and baby stimulation. The independent variable was the workshop on lactation management and infant stimulation.

Operational Definition Of Research : The skills of FWE mothers in providing breastfeeding practices and baby stimulation are; The behavior of FWE mothers, which is expressed in the form of actions, is able to provide practices for caring for breasts, breastfeeding properly, expressing breast milk and stimulating practices for infants $0-3$ months and infants $3-6$ months. The lactation management and baby stimulation workshop is a learning activity for FWE mothers about breast care, breastfeeding properly, expressing breast milk and stimulation for babies $0-3$ months and babies $3-6$ months.

Research Instrument : Data were collected using a questionnaire to measure the mother's knowledge and observation sheets to measure the mother's skills about breast care, breastfeeding properly, expressing breast milk and stimulating the baby.

Data Analysis : Univariate analysis was used to describe the characteristics of the continuous data sample and categorical data. Bivariate analysis was used to compare the skills of FWE mothers before and after the workshop using the t-test. 


\section{RESULTS}

Table 1 shows that the average FWE mother is 32 years old, all of whom have had children and have breastfed, most have a secondary education level (65\%), and more than half are employed (52\%).

Table 1. Characteristics of the sample (categorical data)

\begin{tabular}{cccc}
\hline Characteristic & Category & Frequency & Percentage \\
\hline Age & $<20$ year & - & - \\
& $20-35$ year & 25 & $31,25 \%$ \\
Level of Education & $>35$ year & 55 & $68,75 \%$ \\
& No School & - & - \\
& Basic Education (Elementary & 21 & $26,25 \%$ \\
& School, and Junior High School) & & \\
& Upper Secondary School & 52 & $65 \%$ \\
Proffesion & Collage & 7 & $8,75 \%$ \\
\multirow{5}{*}{ Number of Children } & Work & 42 & $52,5 \%$ \\
& Does not work & 38 & $47,5 \%$ \\
& 1 Children & 27 & $33,75 \%$ \\
Breastfeeding Child & 2 Children & 23 & $28,75 \%$ \\
& 3 Children & 22 & $27,5 \%$ \\
& $>3$ Children & 8 & $10 \%$ \\
& Ever & 80 & $100 \%$ \\
\hline
\end{tabular}

Table 2. Characteristics of the sample (continuous data)

\begin{tabular}{clcccc}
\hline No & \multicolumn{1}{c}{ Variable } & Mean & SD & Min & Max \\
\hline 1 & Age (Year) & 32 & 7.81 & 23 & 50 \\
2 & Knowledge of Breastfeeding and & 57,86 & 9,09 & 35,00 & 75,00 \\
& Breastfeeding & & & & \\
3 & Stimulation Knowledge & 56.87 & 9.65 & 45 & 70 \\
4 & Breast care skills & 48,38 & 11,88 & 33,33 & 66,67 \\
5 & Breastfeeding skills properly & 48,52 & 8,69 & 33,33 & 66,67 \\
6 & Breastmilk Expressing Skills & 48,59 & 11,69 & 29,17 & 66,67 \\
7 & Baby stimulation 0-3 months & 56,41 & 10,82 & 35,9 & 76,92 \\
8 & Baby stimulation 3 -6 months & 53,88 & 8,76 & 31,25 & 66,67 \\
9 & Mother's atittude & 62,29 & 5,28 & 42,86 & 73,81 \\
\hline
\end{tabular}

Table 2 shows that the average value of knowledge of FWE mothers about breastfeeding and breastfeeding before the workshop was 57.86, the lowest score was 35.00, and the highest score was 75.00. The average value of breast care skills before the workshop was 48.38 , the lowest score was 33.33, while the highest score was 66.67 . The average value of breastfeeding skills correctly before the workshop was 48.52, the lowest score was 33.33 and the highest score was 66.67. The average value of the skill of expressing breast milk before the workshop was 48.59 , the lowest score was 29.17 , while the highest score was 66.67 . The average value of baby stimulation skills $0-3$ months before the workshop was 56.41 , the lowest was 35.9 and the highest score was 76.92. The average value of baby stimulation skills $3-6$ was 53.88, the lowest was 31.25 and the highest score was 66.67. while the average value of the mother's attitude before the workshop was 62.29, the lowest was 42.86 and the highest score was 73.81 . 
Table 3. Knowledge and Skills of FWE mothers before and after the workshop

\begin{tabular}{|c|c|c|c|c|}
\hline & Variable & Mean & SD & $\mathbf{p}$ \\
\hline \multirow[t]{3}{*}{1} & $\begin{array}{l}\text { Knowledge of breastfeeding and } \\
\text { breastfeeding }\end{array}$ & 25 & 7.81 & \\
\hline & Before the workshop & 57,86 & 9,09 & $<0.001$ \\
\hline & After the workshop & 86,5 & 4,00 & \\
\hline \multirow[t]{2}{*}{2} & $\begin{array}{l}\text { Stimulation Knowledge } \\
\text { Before the workshop }\end{array}$ & 56.87 & 9.65 & \\
\hline & $\begin{array}{l}\text { After the workshop } \\
\text { Breast care practice }\end{array}$ & 88.87 & 5.47 & $<0.001$ \\
\hline 3 & $\begin{array}{l}\text { Before the workshop } \\
\text { After the workshop }\end{array}$ & $\begin{array}{c}48,38 \\
84,6\end{array}$ & $\begin{array}{c}11,88 \\
3,18\end{array}$ & $<0.001$ \\
\hline 4 & $\begin{array}{l}\text { Practice breastfeeding properly } \\
\text { Before the workshop } \\
\text { After the workshop }\end{array}$ & $\begin{array}{c}48,52 \\
86,8\end{array}$ & $\begin{array}{l}8,69 \\
4,16\end{array}$ & $<0.001$ \\
\hline \multirow[t]{2}{*}{5} & $\begin{array}{l}\text { Practice how to express breast } \\
\text { milk }\end{array}$ & & & \\
\hline & $\begin{array}{l}\text { Before the workshop } \\
\text { Before the workshop }\end{array}$ & $\begin{array}{c}48,59 \\
86,6\end{array}$ & $\begin{array}{c}11,69 \\
6,08\end{array}$ & $<0.001$ \\
\hline \multirow[t]{2}{*}{6} & $\begin{array}{l}\text { Stimulation practice } 0-3 \text { months } \\
\text { Before the workshop }\end{array}$ & 56.41 & 9.65 & $<0.001$ \\
\hline & $\begin{array}{l}\text { After the workshop } \\
\text { Stimulation practice } 3-6 \text { months }\end{array}$ & 86.92 & 4.23 & \\
\hline 7 & $\begin{array}{l}\text { Before the workshop } \\
\text { After the workshop }\end{array}$ & $\begin{array}{l}56.41 \\
87.89\end{array}$ & $\begin{array}{l}9.60 \\
3.53\end{array}$ & $<0.001$ \\
\hline 8 & $\begin{array}{l}\text { Cadre atittude } \\
\text { Before the workshop } \\
\text { After the workshop }\end{array}$ & $\begin{array}{c}62,29 \\
89,9\end{array}$ & $\begin{array}{l}5,28 \\
6,22\end{array}$ & $<0,001$ \\
\hline
\end{tabular}

Table 3 shows the results of data analysis using the t test, namely the average value of knowledge of breastfeeding and breastfeeding after the workshop (mean $=86.5 ; \mathrm{SD}=4.00)$, which is higher than before the workshop (mean $=57.86 ; \mathrm{SD}=9.09$ ). The average value of knowledge about infant stimulation after the workshop (mean $=88.88 ; \mathrm{SD}=4.97$ ). The average value of breast care after the workshop was higher (mean $=84.6 ; \mathrm{SD}=3.18$ ) than before the workshop $($ mean $=48.38 ; \mathrm{SD}=11.88)$. The average value of breastfeeding practice correctly after the workshop (mean $=86.8 ; \mathrm{SD}=4.16$ ) was higher than before the workshop (mean = 48.52; $\mathrm{SD}=8.69$ ). The average value of the practice of expressing breast milk after the workshop (mean= 86.6; $\mathrm{SD}=6.08$ ) was higher than before the workshop (mean=48.59; $\mathrm{SD}=11.69$ ). The average value of baby stimulation $0=3$ months after the workshop (mean $=$ 86.92 ; $\mathrm{SD}=4.23$ ) was higher than before the workshop (mean $=56.41$; $\mathrm{SD}=10.82$ ), the average value of stimulation Infants $3-6$ months after the workshop (mean $=87.89 ; \mathrm{SD}=$ 3.54 ) were higher than before the workshop (mean $=53.88 ; \mathrm{SD}=8.76$ ). The average value of cadre attitudes after the workshop (mean $=89.9 ; \mathrm{SD}=6.22$ ) was higher than before the workshop $($ mean $=62.29 ; \mathrm{SD}=5.28)$, and statistically significant $(\mathrm{p}<0.001)$.

During the workshop, FWE mothers were able to follow the explanations and practices carefully and enthusiastically, and seemed happy to participate in learning about breastfeeding and stimulation. Besides that, it is also explained about mother's milk contained in the Al- 
Quran al-karim, it really touches the mother's feelings, because breastfeeding is obligatory and breastfeeding is a miracle given by Allah, which, God willing, will be a mercy and blessing. Hopefully this workshop on breastfeeding and stimulation can be disseminated to relatives, relatives and neighbors, and be useful for increasing optimal growth and development of children, .

\section{DISCUSSION}

\section{Workshop On Lactation Management And Baby Stimulation}

Breast milk is the right nutrition to support the growth, health, and development of babies to the maximum so that exclusive breastfeeding is recommended as long as it is still sufficient for the baby's needs. Exclusive breastfeeding is given for six months and to monitor its adequacy, a growth assessment can be carried out (Sjarif et al, 2015).

Exclusive breastfeeding coverage in Indonesia and in other countries has not yet reached the $70 \%$ target; WHO targets exclusive breastfeeding coverage of $70 \%$ until 2030 . Knowledge about exclusive breastfeeding must be known to all mothers and families. Maternal and Child Health Service workers should evaluate the mother's knowledge and attitude at each visit. According to Zhang et al. (2018), knowledge of breastfeeding is the most important factor in exclusive breastfeeding behavior, giving mothers opportunities that have a positive impact on women's attitudes to exclusive breastfeeding.

Intervention to increase knowledge of early initiation of breastfeeding and the practice of exclusive breastfeeding is important. Vijayalakshmi et al. (2015), mothers agree with colostrum, maintaining baby's immunity is important $(99.2 \%)$, mothers answer exclusive breastfeeding for the first 6 months $(85.2 \%), 68 \%$ say that breastfeeding should be continued until 2 years (68\%), the importance of burping after each meal (91.8\%), consuming healthy food (98.4\%) and breastfeeding helps mother and child bond (97.5\%). The results show that mothers have good knowledge about breastfeeding, but exclusive breastfeeding is still low.

Social support for breastfeeding needs to be done. According to Balkrishan (2013), people do not know about breastfeeding related to Islamic religious orders. According to Clark (2016), the lack of social network support that is an indicator of a mother's decision to breastfeed, coupled with social norms, can result in women choosing formula milk.

According to the Ministry of Health (2013), building mother's confidence and providing support is important. The skills of building mother's confidence and providing support include: (1) empathy for mothers, (2) giving motivation and enthusiasm, (3) giving examples of how to do it, (4) adding related information, (5) language can be understood, (6) give suggestions, not orders.

According to Rosin and Grkovic (2016), integrated breastfeeding social support is an integrated support for sustainable health care providers so that this social support is expected to contribute to the efficiency and quality of patient health. Margado et al (2013) stated that low social support has three times more likely to consume artificial milk, the role of networks and for that social support deserves attention.

Breastfeeding support that has been carried out includes: (1). Spouse support; mothers who do not have partner support, are more likely to stop breastfeeding during the birth period (Ogbo et al, 2017). (2) Antenatal special class interventions, social support interventions and costs have more significant results (Bruce, 2015), (3). Family support; the highest cause of cessation of exclusive breastfeeding is the lack of family support (Sjarif, 2015), (4). Peer support; peer support and community members, to disseminate knowledge and maximize the reach of breastfeeding support throughout the community should be carried out (Thomson et al, 2015), (5) proactive peer support via telephone during the postnatal period increases exclusive breastfeeding (Forster, 2014). (6) Increased knowledge and 
patterns of exclusive breastfeeding are the influence of mother's participation in breastfeeding support groups (Nurrahmah, 2016).

According to WHO/Unicef (2018), the ten steps for successful breastfeeding include; (1) Having a breastfeeding policy and regularly communicating it to all health workers. (2) Train all health care staff. (3) Inform all pregnant women about the benefits and management of lactation. (4) Initiate early breastfeeding immediately after birth within at least 1 hour. (5) Teaching mothers how to breastfeed, (6) Giving newborns only breast milk without any food, unless there is a medical indication. (7) Carry out hospitalizations Hospitalizations 24 hours a day. (8) Encourage breastfeeding on demand. (9) Do not give pacifiers. (10) Increase the formation of breastfeeding support groups and refer mothers to delivery services if there are breastfeeding problems.

Given the proven benefits of breastfeeding, breastfeeding should be supported by all mothers. According to Rollins et al. (2016), breastfeeding support requires optimal actions ranging from policies, attitudes, social norms, and services, including; (1) Strong promotion of breastfeeding, including saving lives and money, (2) Positive attitude towards breastfeeding (3) Adequate breastfeeding facilities), (4) Enforce relevant laws against the breastmilk substitute industry, (5) Monitor interventions by using tested and effective interventions, (6) The authority of political institutions pays attention to children's rights and women's health.

To get children who have optimal growth and development, not only give exclusive breastfeeding, then complementary foods are given after the baby is 6 months old, then breast milk is given until the age of 2 years. In addition, it is important to stimulate the baby from birth to the age of 6 years.

Stimulation is an activity that stimulates children's basic abilities to grow and develop optimally. It is important for mothers and families to know which aspects of development are monitored. With stimulation, we can detect early deviations in the growth and development of children (Draguscn, 2017). Stimulation of the baby is important to do from the beginning because it will determine the growth of the next stage of development (Santrock, 2007).

According to the Ministry of Health (2018), the first 1000 days of life (starting from pregnancy), is a "golden period", a critical period that is very important in the growth and development of the human brain, which will never be repeated: children receive various learnings, influences from the surrounding environment. This period should be used to teach positive values, and provide exclusive breastfeeding, complementary foods after 6 months of age (balanced nutrition), and provide appropriate stimulation. Early stimulation is important to be carried out continuously. To achieve optimal growth and development, it is necessary guidance on: Stimulation, Detection, Early Intervention for Child Development (SDEICD). According to the Ministry of Health (2016), the benefits of SDEICD are: (1) stimulating the brain so that toddler development takes place optimally, (2) to detect or find deviations in growth and development toddlers, (3) Perform early intervention or corrective action so that their growth and development returns to normal normal or the deviation is not getting worse, and (4). Do as early as possible according to the indications.

Knowledge about breastfeeding, breastfeeding, lactation management and stimulation is still not widely known to the public. Therefore it is important to disseminate it to the public. The counseling carried out so far is from health workers, while health workers carry out so many service tasks. There needs to be support from mothers who are directly side by side with pregnant and lactating women and their families. Therefore, the provision of workshops for FWE mothers on breastfeeding, lactation management and stimulation, becomes additional knowledge and will be able to provide information support and support for pregnant women and their families in their area.

\section{The Effect Of The Workshop On The Knowledge And Skills Of FWE Mothers Regarding Lactation Management And Infant Stimulation.}

The results of the workshops conducted showed that the average value of knowledge about breastfeeding, breastfeeding and stimulation after the workshop was higher than before the workshop. The skills of breast care, breastfeeding properly and expressing breast milk after the workshop were higher than before the workshop. Likewise, the attitude of FWE mothers after the workshop was higher 
than before the workshop. Thus knowledge about breastfeeding, breastfeeding and lactation management should be given to the community. In connection with the dense workload of health workers, the support of FWE mothers needs to be followed up to motivate pregnant women in the surrounding community, then workshops like this can be continued in FWE mothers in other areas so that FWE mothers can be empowered, so breastfeeding, breastfeeding and stimulation is a necessity for good growth and development for the future of their sons and daughters.

\section{RESEARCH FUNDING SOURCES:}

Institution: Muhammadiyah University of Gresik

\section{THANK YOU NOTE :}

The author would like to thank the village head of Karangpoh Gresik Village who has given permission and convenience for us to carry out this research. In addition, FWE women: Neighborhood Association (NA)1, Citizens Association (CA) 05, NA 2, CA 05, NA 3, CA 05, NA, CA 04, who have agreed to be research subjects in our study.

\section{REFERENCE}

Alimoradi F, Javadi M, Barikani A, Kalantari N, Ahmadi M. 2014. An Overview of Importance of Breastfeeding. J Compr Ped; 5(2):e14028; ISSN: 225 - 8150. Online: 22518177.5 (2),e14028. PubMed.

Balkrishan, 2013. Exploring gender: Islamic Perspectives on Breastfeeding. Int Res $J$ of SocScien. ISSN 2319-3565;2(6):30-4.

Bernard JY, De Agostini M, Forhan A, Alfaiate T, Bonet M, Cham- pion V (2013). Breastfeeding duration and cognitive development at 2 and 3 years of age in the EDEN mother child cohort. J Pediatr;163(1):36-42.

Bruce R. Maycock, Jane A. Scott1, Yvonne L. Hauck. A study to prolong breastfeeding duration: design and rationale of the Parent Infant Feeding Initiative (PIFI) randomised controlled trial. BMC Child \& Birth. 2015;5:159.

Cartagena DC, Ameringer SW, McGrath J, Jallo N, Masho SW, Myers BJ (2014). Factors Contributing to Infant Overfeeding with Hispanic Mothers. JGONN; 43:139-59.

Clark A (2016). The role of social support in breastfeeding experiences among rural women in southern appalachia. Department of Nutrition and Health Care Management. Graduate School Appalachian State University:6-7

Deoni SCL, Dean DC, Pirytinsky I, Muircheartaigh J, Waskiewicz N , Lehman K, Han M, Dicks H (2013). Breastfeeding and early white matter development: A cross-sectional study. NeuroImage; 82:77-86.

Departemen Kesehatan RI (2013). Pelatihan Konseling Menyusui. Direktort Jendral Bina Gizi masyarakat. Jakarta.

Depkes RI. 2013. Pelatihan Konseling Menyusui. Direktort Jendral Bina Gizi Masyarakat. Jakarta. Diakses tanggal 22 April 2018.

Forster DA, McLachlan HL, Davey NA, Amir LH, Gold L, Small R, Mortensen K, Moorhead AM, Grimes HA, McLardie FE. 2014. Ringing Up about Breastfeeding: a randomised controlled trial exploring early telephone peer support for breastfeeding. BMC pregn Childb; 14:177.

Gunderson EP (2008). Breast-feeding and diabetes: Long-term impact on mothers and theirinfants. INH Public Access; 8(4):279-86.

Huang, Vaughn, Witko. 2014. Breastfeeding and Trajectories of Children's Cognitive Development. HHS Public acces. Dev Sci. 2014 May; 17(3): 452-461. Pubmed Central (PMC) 3997588. 
https://pusdatin.kemkes.go.id/resources/download/pusdatin/profil-kesehatan-indonesia/ProfilKesehatan-Indonesia-Tahun-2015.pdf

https://www.slideshare.net/mansurasayful/profil-kesehatanindonesia2013

Ibrahimzadeker B, Abadi R (2012). The prevalence of obesity and its Relitionship with mother age, Birth Interval and type of milk Consumption in Children under 5 years in Torkaman Seaport City. J Kerman Univ Med Sci. 2012;19(4):384-91.

Kemenkes. 2013. Profil Kesehatan Indonesia.

Kemenkes. 2014. Profil Kesehatan Indonesia. https://pusdatin.kemkes.go.id/resources/download/pusdatin/profil-kesehatanindonesia/profil-kesehatan-indonesia-2014.pdf

Kemenkes. 2015. Profil Kesehatan Indonesia.

Kemenkes. 2016. Profil Kesehatan Indonesia. https://pusdatin.kemkes.go.id/resources/download/pusdatin/profil-kesehatanindonesia/Profil-Kesehatan-Indonesia-2016.pdf

Kemenkes. 2017. Profil Kesehatan Indonesia. https://pusdatin.kemkes.go.id/resources/download/pusdatin/profil-kesehatanindonesia/Profil-Kesehatan-Indonesia-tahun-2017.pdf

Kemenkes. 2018. Tumbuh Kembang Optimal Dengan Stimulasi, Deteksi Dan Intervensi Dini Tumbuh Kembang (SDIDTK). http://kesga.kemkes.go.id/berita-lengkap.php?id=45. Diakses tanggal 8 November 2018.

Kemenkes. 2018. Tumbuh Kembang Optimal Dengan Stimulasi, Deteksi Dan Intervensi Dini Tumbuh Kembang (SDIDTK). http://kesga.kemkes.go.id/berita-lengkap.php?id=45. Diakses tanggal 8 November 2018.

Kramer MS, Aboud F, Mironova E, Vanilovich I, Plat RW, Matush, Igumnov S, Fombone E et al (2008). Breastfeeding and child cognitive development: new evidence from a large randomized trial. Arch Gen Psychiatry;65(5):578-84.

Mayer-Davis EJ, Dabelea D, Lamichhane AP, D'aguostino RB, JrLiase AD, Thomas J, et al .2008. Breast-feeding and type 2 diabetes in the youth of three ethnic groups: the SEARCh for diabetes in youth case-control study. Diabetes Care;31(3):470-5.

Morgado CMC, Werneck GL, Hasselmann MH. 2013. Social network, Social support and feeding habits of infant in their fourth month of life. Cienciae Saude Coletiva; 18(2):367-76. SciELO.

Nurrahmah A. 2016. Peningkatan Pengetahuan dan pola menyusui eksklusif melalui keikutsertaan dalam kelompok pendukung ASI di Puskesmas Nusukan Surakarta. Jurnal GASTER; 14(2):7-16.

Ogbo FA, Eastwood J, Page A, Arora A, McKenzie A, Jalaludin B, Tennant E, Miller E, Kohlhoff J, Noble J, Chaves K, Jones JM, sépiSmoleniec J, Chay P, Smith B, Oei JL, Short K, Collie L, Kemp L, Raman S, Woolfenden S, Clark T, Blight V, Eapen V, Research Group. 2017. Prevalence and determinants of cessation of exclusive breastfeeding in the early postnatal period in Sydney. Internasional Breastfeeding Journals; 12(16):1-10. BMC.

Quigley MA, Hockley C, Carson C, Kelly YJ, Renfrew MJ, Sacker A (2012). Breastfeeding is associated with improved child cognitive development: A population-based cohort study. J of Pediatr; 160(1):25-32.

Riskesdas. $2018 . \quad$ Hasil Utama Riskesdas Tahun 2018. https://drive.google.com/file/d/1Vpf3ntFMm3A78S8Xlan2MHxbQhqyMV5i/view. Diunduh tanggal 20 April 2019.

Rollin NC, Bhandari N, Hajeebhoy N, Horton S, Lutter CK, Martines JC, Piwoz EG, Richter LM, Victora CG. 2016. Why invest, and what it will take to improve breastfeeding 
practices?. The Lancet Breastfeeding Series Group; 387(10017):491-504. Dep Matern Newborn Child and Adolescent Health. Switzerland.

Rosin SI and Grkovic IZ. 2016.Towards integrated care in breastfeeding support: a crosssectional survey of practitioners' perspectives. International Breastfeed J; 11(15):1-17. Biomed Central.

Santrock. 2007. Child Development. Erlangga: Vol. 1. Edisi XI. McGraw-Hill Companies Inc. Texas Dallas.

Schnooyi S, Khalkhali HARI, Rahimi-Rad MH (2012). The Relationship between Duration of Breastfeeding and risk of Asthma in 2-8 years old children. Urmia Med J;23(1):1-6.SE-

Schwarz EB, Brown JS, Creasman JM, Stuebe A, McClure CK, Van Den Eeden SK (2010). Lactation and maternal risk of type 2 diabe- tes: a population-based study. Am J Med;123(9):863 e1-6.

Silvers KM, Frampton CM, Wickens K, Pattemore PK, Ingham T, Fishwick D (2012). Breastfeeding protects against current asthma up to 6 years of age. J Pediatr:160(6):991-6e1

Sjarif DR, Yuliarti K, Lestari ED, Sidiartha L, Nasar SS, Mexitalia M (2015). Rekomendasi Praktek Pemberian ASI berbasis bukti pada Bayi dan Balita di Indonesia untuk mencegah malnutrisi. Jakarta. IDAI.

Spaulding DM, Gore R (2009). Breastfeeding Self-Efficacy in Women of African Descent. J Obstet Gynecol Neonatal Nurs; 38(2): 230-43.

Stuebe AM, Schwarz EB, Grewen K, Rich-Edwards JW, Michels KB. 2009. Duration of lactation and incidence of type 2 diabetes. JAMA;294(20):2601-10.

Thomson, Marie-Clare Balaam, Kirsty Hymers. Building social capital through. 2015. breastfeeding peer support: insights from an evaluation of a voluntary breastfeeding peer support service in North-West England. International Breastfeeding Journal. $2015 ; 10: 15$.

UU Kesehatan. 2009. Nomor 36 pasal 128 Tentang Kesehatan. https://jdih.kemenkeu.go.id/fulltext/2009/36tahun2009uu.htm . Diakses pada tanggal 15 Agustus 2018

Vijayalakshmi P, Susheela T, Mythili D (2015). Knowledge, attitudes, and breast feeding practices of postnatal mothers: A cross sectional survei. Int J Health Sci; 9(4):364-374.

Villegas R, Gao YT, Yang G, Li HT, Elasy T, Zheng W. 2008. Duration of breast-feeding and the incidence of type 2 diabetes mellitus in the Shanghai Women's Health Study. Diabetologia;51(2):258-66

WHO. 2018. Implementation Guidance; Protecting, promoting and supporting breastfeeding in facilities providing maternity and newborn services: the revised. Baby-Friendly Hospital Initiative. 2018. UNICEF., WHO. ISBN 978-92-4-151380-7

WHO. 2018. Guideline; Counselling Of Woman to Improve Breastfeeding Practice.https://www.who.int/health-topics/breastfeeding\#tab=tab_1. Diakses 5 Oktober 2019.

WHO/UNICEF. 2019. Global Breastfeeding Scorecard. Increasing Commitment To Breastfeeding Though Funding And Improved Policies And Programmes.https://www.who.int/nutrition/publications/infantfeeding/global-bfscorecard-2019/en/ . Diakses pada tanggal 5 Oktober 2019.

Zhang Z, Zhu, Zhang L, Wan (2016). What factors influence exclusive breastfeeding based on the theory of planned behaviour. Midwifery; 62: 177-182 